\title{
6. Planting the Flag
}

\author{
Elizabeth G. Traube
}

If the [national] flag came from the sea, it would be as if foreigners still ruled us.

\section{Introduction}

The Austronesian mythology of the stranger king links political order to an encounter between an indigenous presence and a newcomer from somewhere beyond the borders of the realm, often from overseas. Typically, their encounter involves a transfer of power whereby the newcomer takes over functions formerly vested in the indigenous authorities and is installed as ruler of the realm. Origin narratives of this general type are commonly associated with diarchic systems of leadership, in which political power over humankind and ritual authority over the cosmos are vested in complementary offices. The narrative patterning of diarchic divisions varies. In some narratives, the stranger king becomes the political ruler while the original lords retain ritual authority over the land; in others, the newcomer usurps ritual authority and subsequently delegates his executive duties to still other outsider figures. The content of such narratives as well as the claims to precedence they are used to support also vary according to whether the story is told from the perspective of the newcomers or of the original inhabitants of the land. What such accounts share, James J. Fox (1995b) has argued, is an Austronesian 'epistemology of origins' that makes the categorical distinction between 'inside' and 'outside' into a signifier of status distinctions.

With the historical expansion of the Austronesian peoples as its original matrix (Bellwood 1996), the stranger-king mythology could be used to incorporate foreign newcomers as chiefly rulers (Fox 1995b; McWilliam, this volume) and to symbolically distinguish indigenous chiefs from their subjects (Henley 2002; Sahlins 1985). The mythology is also compatible with colonialism and has been used to legitimise the rule of 'real' stranger kings from Europe (Henley 2002; Traube 1986, 1995). Its relevance for nationalist imaginaries is less obvious. In cases where nationhood is secured through a negotiated decolonisation process, nationalist leaders might model themselves on the outgoing colonial rulers to prove their fitness to rule (Li Puma and Meltzoff 1990:79) and claim a form of outsider status. Anti-colonial nationalist movements, however, would seem less hospitable to narratives about outsider rulers. Leaders of protracted anti-colonial liberation struggles that mobilise the subaltern population as 'the people' tend 
to seek legitimacy by claiming 'insider' status. Subaltern participation in such struggles, moreover, is a transformative experience that both reflects and shapes new practices of political imagination.

For many contemporary theorists, however, subaltern perspectives are secondary or marginal to nationalism, which, especially outside the core capitalist nations, has come to be viewed in largely negative terms, as an elite, top-down process. According to Neil Lazarus (1999:73:72), the hostility towards nationalism that characterises recent thinking reflects a persistent neglect of the specificity of particular nations, nationalisms and national movements. Lazarus is especially critical of a tendency to either stigmatise or deny nationalism's 'popular' dimensions. Thus, subaltern classes figure in current theorising either as a potentially violent 'primordial' force manipulated from above or, in post-colonial versions, as an appropriated voice ventriloquised by nationalist elites - a discursive effect that has no intrinsic connection to actual subaltern desires. What is missing from these models is close, located exploration of actual processes of mass mobilisation. Lazarus (1999:117) turns to Ranajit Guha, among other scholars, for his emphasis on elucidating the 'investment of the masses of the colonized historically in various kinds of nationalist struggle'.

Although some scholars have aligned Guha with their own critiques of nationalism as an elitist (Spivak 1988) or derivative (Kelly and Kaplan 2001) discourse, Guha in fact criticises liberal historiography because it 'fails to acknowledge, far less interpret, the contribution made by the people on their own, that is, independently of the elite to the making and development of this nationalism' (1982:3, emphasis in original). In the 'braiding together' of elite and subaltern politics, Guha (1982:6) saw an 'explosive' potential-as often blocked as realised - for the masses to 'break away' and transform elite-initiated nationalist campaigns into vehicles more expressive of their own aspirations. Guha stressed the role of inherited cultural resources in such transformative appropriations; in reworking nationalist movements from below, he observed, subalterns enlist cultural forms with roots in pre-colonial times that have been adjusted to colonial conditions. ${ }^{1}$

In 1974, when leaders of the Fretilin nationalist party in what was then Portuguese Timor devised the symbol of the 'Maubere people', there was more than a little ventriloquising involved. Fretilin was founded in the wake of the overthrow of the Caetano regime, by educated Timorese elites in the coastal capital of Dili, many of them recently returned from university study abroad. The Maubere symbol coded the leadership's claim to speak on behalf of the masses of poor, uneducated rural folk who inhabited the mountainous central

1 For example, Guha elsewhere (1997:60) called attention to the persistence of the dharmic idiom in Indian forms of subaltern resistance. 
interior of Timor. The term was derived from an ethnic stereotype and had a mild anti-colonial tone. Maubere or Mau Bere is a common masculine personal name among Mambai people who occupy the mountains of central Timor-Leste. During the colonial period, the Mambai had acquired a reputation as the most 'backward' (atrasado) ethnic group in the province, and 'Maubere' was used (primarily by Portuguese and Chinese) as a condescending term of reference and address. In taking the Mambai as archetypes of the masses they sought to mobilise, Fretilin leaders claimed insider status by valorizing what the colonial rulers had denigrated.

From early 1973 through to November 1974, I resided in the Mambai district of Aileu, in the mountains $32 \mathrm{~km}$ south of Dili. I witnessed the early stages of decolonisation from the vantage point of people who represented themselves as archetypal 'insiders' and who were initially wary of the political process under way in Dili. Many Mambai viewed the abruptly initiated decolonisation process with apprehension, as a project orchestrated by and for local elites - Timorese who had 'put on trousers' (tam kalsa) and knew little about the people in whose name they claimed to speak.

But the process of 'producing the people' does not end with elite formulations. Over the course of the leadership's efforts to mobilise the masses, official nationalist discourses have been appropriated and reworked from below. I have written elsewhere about the resonance the 'Mau Bere' symbol acquired in Aileu, where it became entangled with a narrative tradition about a martyred prophet (Traube 2007). In this chapter, my focus is on mythical narratives of the origins of rule as they were used before, during and after the Indonesian occupation. From such discourse, I argue, a hybrid notion of popular sovereignty has emerged that blends inherited cultural categories with newer political sensibilities. Viewed from the perspective of an indigenous epistemology of origins, the category of povu - 'the people' - reconfigures an orientation to the inside that was traditionally associated with the cosmic powers of the land and with the ritual authorities who watched over them. Suffering is the primary linkage. Like the beings traditionally associated with the inside, 'the people' undergo an agonistic but productive ordeal that requires compensation. Imagined as the product of the suffering and sacrifices of 'the people', the nation becomes a site from which local people make claims upon the new national-state.

\section{Colonialism, Decolonisation and Stranger Kings}

When I arrived in Aileu in early 1973, the local administrator arranged for me to live in the household of a village (suco) chief. That summer, at the annual census, I was introduced to several men who resided in the suco but whose clan 
origin houses were located in the mountains to the south, in an origin village known as Raimaus. I subsequently visited Raimaus accompanied by one of these men, Mau Balen, and we returned there for the opening stages of the annual agricultural rites. Then we 'crossed over' ( $f a k)$ to Hohul, another village due south of Raimaus, which is represented as its younger brother. To explain the sibling tie, people often invoked a story about two brothers who lived together in Raimaus. One day, the story goes, the elder brother performed an agricultural ceremony while his younger brother was away. When the younger brother returned, he was so angry over this slight that he gathered up all the ancestral sacra in the house - the metal disks, coral necklaces drums and gongs - and set off southward to Hohul, where he founded a new house that stands as younger brother to the Raimaus house. The two villages are also represented as one house, oriented, as Mambai cult houses are, on a north/south axis. In this model, Raimaus is the northern 'door' (damatan), while Hohul represents the innermost, southern section of a house, the umolun, where the house altar post stands and where house sacra are laid out for rituals. That Hohul priests regularly officiate at Raimaus rituals is consistent with this metaphor. Etiquette also prescribes that newcomers enter Hohul by way of Raimaus (a sequence I have endeavoured to follow ever since). ${ }^{2}$ At a lengthy house-building ceremony in Hohul, I met a young Hohul man named Mau Bere, the son of a minor Hohul priest, who agreed to join Mau Balen and I. Over the remaining six months of my fieldwork, the three of us visited many origin villages, and I became lastingly associated with Hohul and Raimaus.

My relationship to Mambai ritual centres was widely represented in binary terms. People contrasted my 'book and pen' (libru nor labis) with 'rock and tree' (hauta nor aia) - the ubiquitous icons of indigenous ritual life - as tropes of our respective ethnic identities. The technology of literacy marked me as a Malaia, a white overseas foreigner, while rock and tree in this context stood for all the indigenous peoples of the land, represented as 'Timorese'. Much emphasis was placed on my status as a 'returning outsider'. It was common knowledge among Mambai that Timorese and Malaia were kin, descended from 'one mother and one father' (inan id nor aman id), whom they always designated with the inclusive first-person plural possessive pronoun. In Hohul and Raimaus, people also preserved more esoteric origin narratives about the creation and peopling of the world, referred to as the 'walk of the earth' (raia ni lolain). Accounts of the origin of rule were embedded in this discourse on world creation. Here I simply note its central themes.

2 I suspect the reliance on Hohul personnel was conditioned by contingent differences in manpower. Leik Mau, who until his death in the late 1970s was universally acknowledged as the 'owner of Hohul' (Hohul ni ubun), had many sons, all of whom had followed their father and become priests. In Raimaus, his counterpart had died leaving only two sons, one of whom was often away serving in the Second Line; they both emphasised that their father had died when they were 'still little' and had passed on 'only a few words' to them. 
Mambai are deeply invested in a mythology of common origins. ${ }^{3}$ Not only all humankind, but all of nature-including animals, plants, rocks, as well as the earth itself - are ultimately descended (in the case of humans, by branching lines too complex to trace) from Mother Earth and Father Heaven (themselves, according to the few who claim to know such things, the divided halves of a still earlier unity). Mount Ramelau in the central interior, which Mambai call Tat Mai Lau, is identified as the first dry land. Originally surrounded by 'water and sea', the mountain centres the cosmos, and there at the centre Mother Earth brings forth the diverse inhabitants of the land. Her firstborn are the non-human phenomena of nature, who stand collectively to human beings as 'elder siblings' ( $k a k a)$ to 'younger siblings' (ali). At first, Mambai say, their elder siblings were animated, and the trees and grasses screamed when people tried to cut them to build their houses. Then Father Heaven imposed what tellers called the 'ban of the interior' (badu hoha nin), removing the power of speech from his elder children, so that the younger ones could use them for their own livelihoods. Human beings, henceforth distinguished as 'speaking mouths' (kuku kasen), are authorised to exploit the 'silent mouths' (kuku molun), but they are also expected to show them respect. According to an ethic of reciprocity, the 'speaking mouths' offer ritual restitution for the suffering they inflict upon their silent elder kin. ${ }^{4}$ As Mambai say of these obligations: 'We must repay them for their fatigue' (Aim ten de seul ro ni kolen).

The human ancestors are internally differentiated by the patrimony they receive from Father Heaven. To Au Sa, the firstborn or 'head man' (maen-ulun), went the 'nail and hammer, the bellows and forge' (karifi nor maknuta, toh-matan nor rai-inun); he wandered off to the west, taking with him his blacksmithing skills, and he played little part in the stories I was told. These centred on 'middle man' (maen fusun), Ki Sa, claimed as founding ancestor by houses in Hohul and Raimaus, and the lastborn or 'tail-man' (maen-ion), Loer Sa, from whom we Malaia descend. On Ki Sa Father Heaven bestows mystical powers, referred to as his 'luck and fortune' (ubdaida nor fortuna). Meanwhile, the youngest, Loer Sa, draws water from a white spring and 'rinses white, bathes clean' (luk buti, riu $m o$ ), seizes the entire patrimonial collection of regalia of office, and disappears across the northern sea. ${ }^{5}$

I am, it should be noted, splicing together what were far more fragmentary narratives. I have written elsewhere (Traube 1986, 1989) about the tension in Mambai discourse between an aesthetic ideology of narrative plenitude and

\footnotetext{
3 In this respect, Mambai cosmology is reminiscent of Maori creation myths; in contrast, many other Austronesian peoples assume a multiplicity of origins (Fox 1996:231).

4 I find persuasive Graham Harvey's (2006) usage of 'animism' to designate codes of respectful behaviour towards non-human persons.

5 In some accounts, Loer Sa crosses the sea by way of the 'door of the interior' on Tat Mai Lau, taking the 'path of the spirits of the dead' (maeta ni dan).
} 
the partial character of narrative performances. I am more reluctant than ever to over-systematise the narratives of rule I transcribed during my original research, for I believe that what I took to be their (only partially coherent) sequential ordering was in great part the product of my persistent requests for temporal sequence. Indeed, it is the incoherence of myths of rule that most strikes me today - the proliferation of radically diverse, conflicting accounts preserved from different social positions. Nevertheless, while the ordering of mythical events was no doubt always contested, many Mambai insisted that they were part of a single story that could and should be told 'from trunk to tip'. In Hohul and Raimaus, storytellers absorbed Portuguese colonial rule into the story of world creation and wove it together with narratives about the subsequent ordering of the realm.

In the latter, Ki Sa engages with other mythical ancestors in a contest for precedence, which he wins through cunning use of his mystical powers. ${ }^{6}$ Accounts of the contest climax with reiterations of Ki Sa's status as res-res, laulau-literally, 'most-most, top-top'. But despite his supremacy, 'the rule is not heavy, the ban is not weighty' (ukun ba rihu, badun ba mdeda). Loer Sa's theft has left Ki Sa 'with only rock and tree' (nor si hauta nor aia) - the silent tokens of ritual authority. When he displays them to the realm:

Women do not tremble, men do not [show] fear Hina ba rih, maena ba tmau

They stab one another and slay one another $\quad$ Ro sa ro, ro tar ro.

In search of a way out of this anarchic and violent state, Ki Sa uses his 'luck and fortune' to cross the seas and confront his younger Malai brother. On being informed of the situation in the homeland, Loer Sa hands over assorted regalia of sovereign power: named staffs, swords, drums and a flagpole and flag. He pledges to send representatives to Timor later on. Ki Sa returns home, where 'women and men tremble and fear' when he displays the new tokens. Tellers conclude: 'Then the rule was heavy and the ban was weighty' (Ukun rihu sois, badun dmeda sois).

In other versions of the quest narrative, Ki Sa's descendants are the ones who make the journey overseas. By some accounts, there are two separate visits, the first to obtain the regalia, and then, when peace is again disturbed, a subsequent visit to ask the Malaia to return in person. Such doubling is not without precedent - for example, a Balinese tradition describes two successive delegations to Majapahit to receive regalia from the ruler (Fox 1995b). Still, it always seemed to me that Hohul and Raimaus tellers were labouring to subsume

6 The contest for precedence is a widespread Austronesian theme; in many traditions, the trickster is an outsider or latecomer who defeats an established indigenous ruler (Fox 1995b), but in Hohul and Raimaus versions, the contest takes place in an open field of insiders. 
within a single overarching story two different narrative bases for their villages' claims to precedence: the claim that Hohul and Raimaus ancestors had brought the Malaia back to Timor as supreme political rulers and the claim that their ancestors were the first settlers and original lords of the land who had later 'turned over the rule' (sra ukun) to indigenous newcomers from outside the realm.

The second claim, which relates to local diarchic arrangements, was asserted repeatedly, with considerable passion, and continues to be invoked today. Yet especially in contrast with the epic story about the Malaia, narrative accounts of these local events seemed thin. Hohul and Raimaus people depict their surrender of rule as a voluntary act, rather than the outcome of a contest or defeat. Once having ordered the realm, their ancestors simply grow old and weary; they 'sit down to look after the rock and watch over the tree', retaining their ritual function, while they 'hand over the rule' (sra ukun) - embodied in named drums and flags from overseas - to later arrivals to the realm: the leaders of an origin village known as Bandeira Fun ('base of the flag'), who become the rulers of the kingdom known as Aileun. Bandeira Fun, by all accounts, is originally the home of one Bau Meta, who later 'surrenders the rule' to inmarrying strangers from the house of Bar Tai. Although Bau Meta's line has no descendants, his house is maintained in Bandeira Fun, next to Bar Tai. After his death, his head turns into a twisted tree (ai-leun), from which the kingdom of Aileun takes its name; the name of the kingdom was in turn extended to the colonially created administrative district of Aileu. ${ }^{7}$

Bau Meta is also the protagonist in a well-known tradition that shares motifs and themes with tales told by other ethnic groups (see Bovensiepen, this volume). In this tradition, he owes the title of 'Dom' to certain spirits of the land whom Mambai call rai ubun - owners or masters of the earth. The term is equivalent to the Tetun rai nain, but unlike many other Timorese peoples (see McWilliam, this volume), Mambai never apply it to human beings. To my knowledge, it is used solely to designate a class of spirits associated with 'wild' (hui), uninhabited spaces; their counterparts are the 'sacred objects' (saun lulin) that are kept sequestered inside clan origin houses and which Mambai distinguish in this context as 'tame' (maus).

Bau Meta, the story goes, went out one morning to tap his palm trees; by afternoon, the buckets were filling with palm wine, but when he came back the next morning, they were empty. After the same thing happened several times, he hid himself near the trees to observe. Late at night, two young girls appeared and drained the buckets. Bau Meta demanded to know who they were and

7 'Ai-leun', Mambai are fond of observing, 'is not in Aileu [the district capital], but in Bandeira Fun'. I use 'Aileun' to designate the kingdom and 'Aileu' for the administrative district and its capital town. 
why they had been stealing his wine. Their mother and father, they told him, had ordered them to do so, and they took him home to meet their parents, who were spirit 'owners of the land' (rai ubun). They instructed him to go to Dili, where they said the Malaia would soon arrive from overseas and would make him a great ruler. Bau Meta did as the spirits instructed and was recognised by the Malaia. They presented him with a book that conferred on him the status of 'Dom', making him superior to the Mambai ruler of the coastal kingdom of Motain. ${ }^{8}$ But later on, Bau Meta went to visit the Motain ruler and was seduced by his wife, who stole the book while he slept and gave it to her husband. As a result, the order of precedence was reversed and Motain became superior to Aileun.

I have heard this story many times, from many people; it is common knowledge, a genuinely popular tale, usually told in prose rather than poetic ritual language. Bau Meta's misadventure in the denouement - typically narrated in a tone of comic self-deprecation-expresses an ethnic stereotype of Aileu Mambai as foolish 'maubere' highlanders, easily outwitted by cleverer coastal folk. In many accounts, the episode motivates Bau Meta's subsequent abdication to his Bar Tai wife-takers, having proved himself unfit to rule through his stupidity.

Hohul and Raimaus people also tell the Bau Meta tale, which they refer to as 'recent' (fnoir). In their accounts, the Koronel Aileun are politically subordinated to both Motain and the Malaia, and are also obligated to show deference to Hohul and Raimaus (the 'old mother/old father'), who are the original sources of rule. Formerly, people said, Aileun's deference included bringing gifts of salt and livestock from Motain on the northern coast (taisa) to Hohul and Raimaus in the southern interior (hoha), in return for harvest gifts that Hohul and Raimaus collected from outlying villages and sent to the coast. Indigenous tribute systems of this type linking coastal and highland chiefs had been replaced at the end of the nineteenth century with the colonial head tax; the replacement was deeply resented in Hohul and Raimaus, where the Aileun rulers rather than the Malaia were held accountable. Nevertheless, Aileun remained obligated to bring water buffalo to Hohul and Raimaus house ceremonies, and that obligation was a source of great pride in the ritual centres.

At least as viewed from the ritual plane, installed outsiders (whether the Malaia or Aileun) do not come to represent the inside, as occurs in some other diarchic systems (Fox 1995b). Mambai ritual authorities who claim precedence as the original sovereigns are categorically associated with the inside, the sphere of rock and tree, while political executives are associated with the outside, the

8 Fernando, Mau Bere's younger brother, offered a particularly clever explanation of the doubled-donor function. In his account (narrated in 2001), the spirits tell Bau Meta that they cannot give the book to him directly because he is illiterate and thus no-one will believe he is its rightful owner. In order for the book to command respect, the spirits explain, it must be publicly bestowed on him by the Malaia. 
sphere of women and men. The situation is complex, as distinctions between inside/outside are replicated at multiple levels within both diarchic poles: in Bandeira Fun, Bau Meta's empty house is maintained as the passive sacred, inner counterpart to the active ruling house of Bar Tai, while within both Hohul and Raimaus distinctions are made between particular houses and functionaries oriented to the inside and others, which represent the villages to the outside world. It is nevertheless possible to portray the diarchic relationship in terms of a distinction between what I will call 'interiority' and 'exteriority'. Ritual or spiritual authority - defined as an orientation to the inner realm of silent, life-giving, non-human persons - immobilises the subject, while political rule entails an orientation to the outside, the volatile sphere of human affairs, and requires continuous mobility. This distinction can be represented as a gendered contrast between female and male, and Mambai would sometimes directly compare their ritual authorities with housebound women, as many other Timorese peoples do (Cunningham 1965; Fox 1995b; McWilliam 2002; Therik 2004). Ritual leaders also participate in the darkness attributed to Mother Earth, whereas political rulers have symbolic associations with Father Heaven. I have argued elsewhere (Traube 1986:104-5), however, that age is emphasised over gender in Mambai discourse, and the point is consequential. As 'old mother/ old father', ritual leaders evoke the cosmic couple, whose union they ritually secure, while their relative age also evokes the silent rocks and trees, whose immobility and fixity they share. They are the encompassing part that stands for the whole, and the ritual gatherings they preside over symbolically recreate the totality before division (Valeri 1989).

Confined to a perpetual vigil over the cosmic beings, sacral leaders are ignorant of worldly affairs. They represent themselves as 'stupid and dense' (beik nor bodu), literally closed off to external stimuli, with 'heads that are still whole, ears that are still full' (ulun hi tema, kikan hi benu), like a newborn child. But where Bau Meta's stupidity is laughable and disqualifies him as supreme political ruler, the perceptual closure attributed to ritual authorities entails a deeper wisdom - a knowledge of origins that is implemented in ritual. Political chiefs, in contrast, are depicted as sharp-sensed, vigilant and mobile, 'dog-nosed and bird-eyed' (inun ausa, matan mauna) sentries, whose portion of ritual sacrifices is the leg ('in order to walk'). Where spiritual wisdom involves a condition of closure, political rulers are perceptually open, attuned to the volatile outside world that they oversee.

The oppositional symbolism of diarchic functions is widely shared, but its narrative ordering is contested. Aileun recognises the ritual authority of Hohul and Raimaus, but not - at least as far as I could ever ascertain - their claim to precedence as original donors of political rule. Yet in Hohul and Raimaus, people believed that their status as founders of the realm made them vulnerable 
to accusations of usurpation; they insisted that Aileun rulers suspected them of a desire to 'seize the rule' (hau ukun) and take back that which they had once 'handed over' (sra). A story that Mau Bere's younger brother Fernando told me in 2001 conveys the ambiguities, as seen in Hohul, and I repeat it here. ${ }^{9}$

Some years before my first visit, Fernando recounted, Hohul was rebuilding its sacred houses. As is customary, they also planned to replace the flagpole - the token of their ancestor's quest overseas - and they had cut down a tree for this purpose. But the Aileun rulers grew suspicious: 'Hohul is not Koronel', they said, 'that office belongs to us', and they ordered Hohul to transport the fallen tree to their village, Bandeira Fun (which literally means 'base of the flag'). But when the people tried to obey, the tree turned into a snake and glided back towards Hohul, where it turned back into a tree. They tried once more to remove it, but it grew too heavy to lift, so they left it where it was and continued rebuilding their houses. When the houses were ready, the tree became light, so they brought it into the village, carved it, and erected it in its customary place.

In this story, the tree-pole knows its proper place, both literally and metaphorically. Its Hohul guardians refer to it as the 'trunk' or 'base of rule' (uku-fun), which it is their task to 'hold' (fail tu) and 'keep steady' (tid). The category $f u$ - 'trunk, base, source, origin, cause' - is a botanical origin category that links the idea of temporal origins to the image of the trunk or stem of a tree (Fox 1995a:5-8). Represented as the 'trunk' of rule, the flagpole encodes a claim to precedence. During my first research, Hohul and Raimaus people had frequent recourse to this botanical origin discourse. They would contrast their position as holders of the trunk of rule with that of political executives: the Aileun chiefs and above them the Malaia, who 'held the tip of rule' (fail tu uku-laun) - that is, the flag. The vertical imagery of rule could be inflected in numerous ways: the flagpole was likened to the digging stick, and thus to the ritually ensured fertility of the earth, while the flag was compared with a shade tree or an umbrella that protects the realm from excessive heat. Another, and arguably primary, implication of the botanical metaphor is that rule might have many 'tips' but it has a single trunk. To Hohul and Raimaus people, their status as original founders and guardians of the trunk of rule entailed the right to legitimise any new successors to office.

This discourse took on heightened significance after April 1974, when the new Portuguese Government embarked on a program of rapid decolonisation. In Dili, three political parties were rapidly formed: Fretilin, UDT (União Democrática Timorense, the Timorese Democratic Union) and Apodeti, their programs based respectively on national independence, federation with Portugal, and integration into Indonesia. Both Fretilin and UDT sought support in the countryside, and

9 Mau Bere died two years before my first return visit. 
a lively debate was soon under way. At the Raimaus house-building ceremony I was attending, people framed the political situation as a problem of succession. Their 'younger brothers', people said, had 'grown old and weary' and would have to 'surrender the rule' to younger, fleeter heirs. Many people voiced fears of a return to the anarchic past; Hohul and Raimaus people warned that such fears would be realised unless all the parties assembled at their villages, for the guardians of the trunk to legitimise a chosen successor.

When I left Timor in November 1974, the Aileun rulers had already declared their support for Fretilin, but it seemed that many people remained uncertain. A year later, however, when a UDT coup disrupted the decolonisation process, Fretilin mobilised the district of Aileu. Aileu Town, the seat of the district, was the site of a Portuguese training centre; Fretilin forces seized its arsenal and distributed the weapons to the local populace, to meet a UDT force advancing from neighbouring Ermera. ${ }^{10}$ The Portuguese colonial administration abandoned the island during the fighting and refused to return when it ended, despite repeated requests from the Fretilin victors. Fretilin leaders, as much as Mambai sacral authorities, had wanted a formal transmission of rule in which they would have ceremonially succeeded the outgoing colonisers. But under the escalating threat of an Indonesian invasion, Fretilin unilaterally declared independence on 3 December 1975. Over the years that followed, Mambai learned that the national flag was unlike other tokens of office; it could not be bestowed by old leaders on new ones, but would have to be won through the suffering and sacrifice of 'the people'.

\section{Under the Rule of the Eldest}

At the time of the invasion, Indonesian authorities forced UDT leaders to sign a letter (the so-called 'Balibo Declaration') calling on Indonesia to restore order. The 'invitation' might well have been designed at some level to legitimise the occupation to the East Timorese populace, as well as to the international community, but at least to the former, its coerced character was evident. ${ }^{11}$ The Indonesian regime received no ideological benefit from the instability its agents had helped to create. The scale and force of the invasion undercut any effort to frame it as the arrival of peace-bringing stranger kings.

\footnotetext{
10 The Carrascalao brothers who founded UDT were major landholders in Ermera, which became the party's base. To what extent the Aileu resistance to the Ermera force was motivated by nationalism or localism is difficult to say.

11 Dated 30 November 1975, the text had actually been prepared in Bali during August by the Indonesian secret service and Timorese collaborators. The text demanded the integration of the territory into Indonesia and asked for help from the Government to this end; many leaders, including those responsible for the UDT coup, were forced to sign in order to be allowed to return to East Timor (Durand 2001:109).
} 
Although Portuguese colonialism had certainly involved violence, Portuguese rule had been gradually extended and, moreover, offered certain advantages to local rulers as well as to their subjects. Over the course of the colonial 'pacification' campaigns, local rulers repeatedly allied with the Europeans against traditional rivals (Pélissier 1996). ${ }^{12}$ For their subjects, the possibility of appealing to impartial European outsiders had its attractions (Henley 2002); whereas local rule was experienced as unjust, even the fantasy of such appeals enabled people to preserve expectations of justice from the higher and more remote colonial authority.

But the Indonesians confronted a nationalist movement that radicalised the political situation, even if it had not instilled a uniform nationalist consciousness. Aileu district had become known as a Fretilin stronghold during the civil fighting, and this reputation put the population at high risk; the majority abandoned their homes and gardens and retreated into the mountains behind Fretilin's armed wing, Falantil. For the next three years, people led an unsettled existence in what they represent as 'the forest' (ai laran), moving between Fretilin base camps, homes of relatives and their ancestral origin villages. In 1978 the Indonesian armed forces began a new advance, based on a combined strategy of saturation bombing and encirclement of the population within a given area (Dunn 2003; Taylor 1999). Unable to protect the civilian population, Falantil encouraged them to surrender and transformed itself into a guerrilla force.

People told me in 2001 that when they surrendered to Indonesian authorities, they would represent themselves as povu, which here means civilians, as opposed to military or forsa, and would claim to have fled out of fear rather than political commitment. Prior loyalties to the resistance were tactically disavowed, as anyone even suspected of Fretilin sympathy was likely to be killed. Yet nationalist loyalty at this point does not appear to have been irreversible. People repeatedly assured me that if the Indonesians had treated them well, they could have come to accept their rule in time. Indonesia's contributions to Timor's material development were readily acknowledged and contrasted with the chronic neglect of the colony on the part of the Portuguese rulers. Indeed, the Indonesians were determined to outdo their colonial predecessors, and they invested heavily in roads and schools, largely but not only for purposes of control (Anderson 1998:134-5). What precluded accommodation was the regime's murderous hostility towards the indigenous population. Civilians who surrendered continued to be subjected to diverse forms of state terror, including arbitrary arrests, torture, disappearances and intensive, continual surveillance. The Indonesian occupiers behaved not as irredentist nationalists towards fellow

12 The kingdom of Aileun was in fact one of the 'loyal allies' of the Portuguese Crown and had participated in both the campaigns against the Manufahi rebels. 
countrymen but as colonisers towards what they regarded as a 'backward' and peculiarly 'ungrateful' population, who in turn perceived the regime as bent on their annihilation. As one Mambai friend put it to me: 'We saw that they wanted the land, but not its people.'

On one occasion in 2001, I asked my old friend Mau Balen and my 'sister' Fatima if they considered Indonesians to be 'Malaia'. The query elicited heated denials. At once and in unison they declared that Indonesians could not be Malaia because they are 'black like us [exclusive]' (meta man aim). When I observed that they referred to Africans as 'black Malaia' (Malai metan), Fatima countered that Africans came from overseas, like other Malaia, whereas Indonesians had come 'by land'.$^{13}$ But Indonesia, I protested, comprised many islands and was at least technically 'overseas'. Fatima grudgingly conceded the point, but even so, she maintained, they referred to other islanders by their particular provenance, as 'Javanese' or 'Balinese' and so on, not as Malaia. ${ }^{14}$ When I continued to look quizzical, they shifted to behavioural distinctions. Indonesians were not Malaia, they said, because they had brought war rather than peace to the land. Mau Balen pointed out that the invaders' claim to have come as helpers was immediately belied by the sheer force of their arrival, with ships, planes and guns that could fire from Dili to Aileu. Fatima, still pondering the sea/land distinction, added that they referred to the continuing stream of immigrants by the Indonesian term pendatang ('settlers'), which she glossed as uninvited guests - people who 'just come' ( $\mathrm{ma}$ lea) and who travel by land (lolai raia).

Various other people with whom I repeated the exercise gave similar responses, excluding the Indonesians from the category of Malaia and from the strangerking slot affiliated with it. Another way that people set the Indonesians apart was by representing them as descended from $\mathrm{Au} \mathrm{Sa}$, the blacksmith eldest brother of the mythical ancestors, Ki Sa and Loer Sa. I suspect that this lineage was already established in the 1970s, though I do not recall having heard it, but in 2001, it seemed to be common knowledge. Like the Malaia, Au Sa's descendants are 'returning outsiders', but they lack the qualifications of a ruler (which can be logically expressed as coming 'by land' rather than from overseas). Au Sa, of course, is also black, like the peoples of the land. Even before the invasion, Mambai frequently rejected Apodeti's integrationist program on the grounds that 'black ruling black is no good'. Such assertions, I think, have less to do with internalised racism than with the old ideology of rule, which posits difference (between exteriority and interiority) as the condition of order. Moreover, as I have noted, historical experience had also provided a pragmatic basis for subaltern preferences for European over indigenous rulers.

13 In fact, the marked term 'black Malaia' indicates that whiteness is the unmarked form of the category.

14 Fatima, who is high school educated, was certainly familiar with the geography of the region; Mau Balen is illiterate and, I suspect, the primary referent of 'Indonesia' for him might be western Timor. 
Ideological legitimation of Portuguese colonial rule never precluded criticism of colonial attitudes and policies. Indeed, it was always possible to construe particular individuals, acts and policies as deviations from the idealised rule of stranger kings, and discourse on such represented lapses amounted to what I have called a 'critique of the rightful rulers' (Traube 1995). But the identification of the Indonesian occupiers with an ancestor who was black, older and of the land neatly amplified their categorical unfitness for political rule and provided symbolic resources for a particularly bitter critique. On the one hand, with its systematic corruption and propensity for extreme state-sponsored violence, the Indonesian regime demonstrated its lack of the 'exteriority' ideally expected of a ruler, who should be an open, perceptive, impartial arbitrator of disputes. On the other hand, in place of the 'interiority' of a properly immobilised ritual leader, Indonesians displayed negative forms of inwardness that showed their intellectual and moral limitations. Fernando, who had a knack for constructing homely analogies, once compared the Indonesians with a provincial elder brother who stays at home and does not develop himself, while his younger sibling leaves home to improve himself through study. A poetic representation of Au Sa portrays the ancestor as reclusive and inhospitable: he 'fears the whinny of the horse, fears the jangle of the bridle' (tmau kud-kiin, tmau freu-hahan). Instead of welcoming guests with generous gifts, he withdraws into himself, refusing the spirit of reciprocity that organises Mambai social life - and so it was with his Indonesian descendants. ${ }^{15}$ In principle, Au Sa's identification as blacksmith eldest brother could have come to signify development and modernisation, but under the brutal conditions of the occupation it conveyed a combination of material power and moral inferiority that many people saw in the Indonesian authorities.

Such symbolic practices both reflected and reinforced experiences of the regime as fundamentally antagonistic to the population; they helped to deflect official efforts to instil a spirit of Indonesian nationalism - which were admittedly weak at best - at the same time as they strengthened an oppositional nationalist identity that might otherwise have been diffused. Mambai constructions of the occupiers belong to the 'arts of resistance' (Scott 1990) — cultural forms through which the dominant are portrayed not as they wish to be seen, but in ways that reaffirm the moral superiority of the dominated. Under the Indonesian occupation, such locally constructed moral communities came to imagine themselves as part of a wider national community of Timorese who were linked by their shared suffering and by their renewed aspiration to political self-determination. In the next and final section, I focus on the cultural construction of a distinctive mode of popular sovereignty grounded in ideas of moral obligation. In contrast with

15 In a somewhat lighter vein, people claimed to have been offended by the Javanese practice of packing up food presented at ceremonies and taking it home to consume in private. 
the liberal rights-bearing subject, 'the people' in Mambai political imagination are those who claim consideration on the basis of what they have suffered for the nation.

\section{The Suffering People}

Although Mambai are familiar with the Portuguese-derived term nasaun, they use it infrequently. Particularised in songs as rai Timor, the nation is most commonly evoked through the metonymy of the 'national flag' (bandeira nasional), which is intimately associated with the idea of povu ('the people'). It is a commonplace that the flag 'was not purchased with silver or gold, but with the blood of the people' (ba los nor os-butin nor os-meran fe al, mas nor povo ni laran).

During the transition to formal independence, the flag referenced in such statements was the flag of the Democratic Republic of East Timor (RDTL), the nation declared by Fretilin in 1975. Although the 'national' status of the 1975 flag was uncertain during the transition, it retained a considerable affective charge. The Fretilin party flag, on which it had been closely modelled, was distinguished from it as the 'political flag', representative of a particular party (albeit still a uniquely prestigious one in early 2001), whereas the 1975 flag was associated with the people as a whole and evoked the ideal unity of the nation. In Aileu, many people expressed concern that the political process under way during the transitional period was dividing the nation instead of uniting it. Sixteen parties, including Fretilin, had been recognised by the United Nations Transitional Administration in East Timor (UNTAET) and authorised to compete in the upcoming constitutional election. ${ }^{16}$ Many Mambai professed to see not democratic freedom in their proliferation, but a troubling and potentially dangerous disunity. People were quick to point out that the formation of parties in 1975 had led to violent conflict, and there was no guarantee that the past would not be repeated. Fuelling that anxiety was a deep suspicion of the new crop of political elites. A widely held and frequently voiced assumption was that the party leaders or 'big people' (tun ro) were pursuing position or status rather than the collective good; literally, they were 'looking for their chairs' (klai kadeira), and had formed parties for that purpose. In this rhetorical vein, speakers often asserted that 'the people' had not suffered and sacrificed for parties but for the national flag.

\footnotetext{
16 To UN 'nation builders', a multiparty system is both a sign and an instrument of democratisation, and many East Timorese elites also believed that unless new parties were encouraged, Fretilin, with its immense cachet, would unduly dominate the political process, but popular opinion remained largely antagonistic to party division. I would argue that the subsequent popularity of the ASDT in Aileu was due in part to local perceptions of it as the 'trunk' or 'source' (fun) of Fretilin, not a new party but the totality before division.
} 
Mau Balen once offered a splendid commentary on the distinction. He began by comparing 'political flags' with 'white blood' or semen - a substance that, as he and Mau Bere had once laboured to explain to me, is productive only when it is combined with female menstrual blood, lar maten (literally, 'dead blood' or 'spilled blood'). So, too, he explained, 'political flags' are 'just talk' - the weightless discourse of party elites who, in 2001, as in 1975, droned on and on about their programs and promises. Like white blood, he said, such discourse was unproductive by itself. It had required the blood shed by the people in the war to produce the flag of the nation.

Mau Balen offered this analogy in the context of a narrative account of the origins of the national flag, which he often recited. Like many nationalist intellectuals, Mau Balen had invented a primordial origin for the nation, projecting it back onto the mythical past. He represented the national flag as Ki Sa's flag- 'the flag of the interior' (bandeira hoha nin) - which he said the ancestor had left behind on Nama Rau (a poetic name for Tat Mai Lau or Ramelau). ${ }^{17}$ This purely indigenous power token was the counterpart to the colonial 'flag of the sea', which the Malaia had taken away and brought back. The interiority of the national flag also figured in Mau Balen's account of the day it was first raised in Aileu, in December 1975. According to Mau Balen, the Hohul priest who had been designated to perform the chant for the flag had represented it as originating overseas. At this, he said, the Aileun rulers had intervened and declared the chant to be incorrect. Mau Balen said he eventually stepped in himself and in a brief chant traced the flag's descent from Nama Rau into the hands of Xavier (do Amaral) and (Nikolau) Lobato.

Mau Balen was not always a reliable narrator, and several people challenged his account of his own role in the flag ceremony (see Traube 2007). But the considerable force of the traditional association of political rule with the sea could indeed generate ambiguities of the sort he described. I once asked a group of Dai Lor ritual leaders where the national flag had originated. Their formulaic response - 'from the water and sea' - prompted Fernando's objection, cited at the beginning of this chapter, that this would be as if foreigners still ruled. Fernando, who is a schoolteacher, did not invent a mythical origin for the national flag. He did, however, on my request, subsequently retell the myth of the colonial flag. He had clearly learned the story from his elder brother Mau Bere, but there was one innovation, which I suspect was his own. In the versions Mau Bere and Mau Balen had recounted for me, the realm's non-response to sacred symbols motivates the quest for the flag, but Fernando amplified the theme of pre-political anarchy and gave it a Hobbesian twist. Before the return of the

17 Fretilin leaders showed their appreciation for the cultural significance of the mountain in selecting the poem Foho Ramelau as the anthem of the nationalist movement. After independence, however, other parties argued that this song was too associated with Fretilin to serve as the national anthem. 
Malaia, he said, everyone had guns, and people would resort to armed violence at the slightest provocation - a situation he described as a negative form of 'selfrule' (uku-lolo). When the Portuguese arrived and took stock of this situation, their first act as sovereign was to compel the Timorese to surrender their arms to the state. 'The guns', Fernando said, 'had to be turned over and stored together, in one place. In the event of a war, they would be redistributed to the forces, to meet the attack.' In this way order was restored, and the Portuguese ruled for 450 years. Nando represented the Portuguese as staying on to give a protracted course in civic education that should have concluded in 1975, when 'the Portuguese gave us liberty' - a reference to the official launching of the decolonisation policy. ${ }^{18}$ But just as people were beginning to understand the different party programs, UDT had 'spoiled' (estraka) things by launching the coup.

It was clear from the context that the motif of the armed and disarmed population refracted recent political events. Earlier in the same conversation, Nando had described Fretilin's seizure of the Aileu arsenal in 1975 and its distribution of the weapons. The more recent arming of anti-independence militias by the TNI (Tentara Nasional Indonesia, the Indonesian military) in August 1999 was also never far out of mind - a reminder of the fragility of civil society. By implicitly incorporating experiences of local armed violence into a mythical narrative, Fernando articulated a shift that was under way in political subjectivity. In the versions of the flag myth that I had recorded in 1973-74, order comes from the cosmic ruler and his human representatives. The subjects of the realm are not called povu but 'women and men', and in the narrative they function not as sources of sovereignty but as obstacles to it. They are negative actors, characterised by their failure to 'tremble and fear', rather than by any innate capacity for citizenship. When they finally recognise and defer to the ruler, they are motivated by the sacred terror that the regalia from overseas inspire.

To return to the pre-political state as represented in the earlier version of the myth would be to relapse into a state of chaos, where people indiscriminately 'stab and slay one another' (a prospect that Mambai often rhetorically evoked, not without cause, as a potential danger). Nando, however, constructed a prepolitical state that allows for a partial, productive return in times of emergency. Much like social-contract theorists, he projected a version of 'the people' onto a mythical 'state of nature' in the form of essentially rational subjects who voluntarily surrender their arms to the colonial state. They are, moreover,

\footnotetext{
18 The Portuguese Government officially recognised the right of the East Timorese to independence (Durand 2001:107) for the first time on 2 May 1975. Like Fernando, a group of Bar Tai people I met with also reconfigured colonial rule as a kind of protracted decolonisation; they said that the Portuguese had come to offer instruction and would have stayed only a short time. But when their appointed representative, Bau Meta, died, they ended up staying for 400 years.
} 
citizens, or citizens-in-training, who can be legitimately rearmed in a national crisis. He adapted the traditional origin narrative and made it consistent with and expressive of a modern political subjectivity.

Not everyone is a storyteller, and most constructions of 'the people' did not take narrative form. The category was continually articulated in everyday discourse, most often in opposition to an imagined elite 'other'. Claims to speak as 'the people' as well as for them took on a populist edge that has persisted and intensified in the post-independence era. In this discourse, suffering is constitutive of national belonging and provides an idiom for challenging the commitments of particular individuals and groups. People in Aileu were well aware and deeply resentful of the claim that easterners had suffered more than westerners during the resistance struggle; in the most generous interpretation, they attributed such views to the easterners' lack of understanding of the early history of the war. Mambai themselves used the idiom of differential suffering to mark the boundaries of 'the people'. Recently returned diasporans were especially vulnerable to exclusion. That some exiles had been active in the resistance and had fled to save their lives was accepted, but the capacity to leave distinguished them. Mobility - in the form of access to planes, boats and passports - was often framed as an index of privilege, while 'the people' had no such resources and remained behind, as much out of necessity as inclination. In the calculus of those who remained behind, whatever suffering homesick exiles might have endured abroad could not come close to their own. Nor was the charge that so-and-so had not truly suffered with the people reserved for returned diasporans; it could be directed against any leader a speaker disapproved of, mistrusted or opposed. In Aileu, José Ramos-Horta remained the privileged exile who was held to have selflessly represented Timor's plight to the world, and Xanana Gusmão was a genuinely popular leader who had shared the people's ordeal, suffering with them in 'the forest' and for them in an Indonesian prison. In contrast, party leaders as a category were suspected of 'using the people's name' (oid povu ni kalan) without having participated in their suffering.

Speakers who identified or affiliated with 'the people' would often represent them as 'stupid' (beik) in contrast with educated (matenek) elites. Used literally, the attribution of stupidity referred to the widespread illiteracy among the rural masses and could be described as a social problem that needed to be overcome. Some individuals also portrayed their personal lack of formal educational qualifications as an index of their prior commitment to the resistance, on the dual grounds that resistance activities had taken time and energy away from schoolwork, and that the regime had rewarded collaborators with educational opportunities, while penalising families suspected of supporting the resistance. In figurative usage, the represented stupidity of the people took on positive 
connotations; it signified a form of popular wisdom or commonsense, while formal learning was characterised as a mode of stupidity. A Tetun proverb that Mambai often recite captures the popular mood: 'We stupid folk procure education; the educated ones return, and they are stupid like us' (Ami beik-teen sosa matenek; matenek mai fail, beik tuir ami).

The most egregious forms of elite stupidity, according to popular opinion, were evidenced in the competitive disunity that characterised politika (politics) - a term that was commonly used in the sense of manoeuvring for power and advantage. Critics pointed to the squabbling and bickering among party leaders as symptomatic of the discord and division that resulted from the political pursuit of self-interest. In contrast, 'the people' were said to understand the need for inclusive unity and to be already unified in their demands; what they expected from the state was assistance in securing 'their livelihood' (ro ni morin). The primary demand made in the name of the people on the state was to promote collective welfare by investing in the agricultural economy.

\section{Conclusion}

Since Timor-Leste's formal independence in 2002, and especially since the breakdown of civil order and security during the political 'crisis' (crize) of April-May 2006, much has happened in Aileu; yet, on the basis of several short return visits, I believe that the themes I have sketched remain salient in popular discourse. I conclude by suggesting that the discourse of 'the people' has tapped and reconfigured older notions of ritual authority.

Both categories embody forms of 'interiority' - a condition that binds subjects to the land and imposes on them a 'stupidity' that is also a form of wisdom. Like the sacral authorities of the indigenous polity, the people are symbolically associated with fixity, immobility and constancy. Although they lack formal knowledge, they have a practical understanding of national needs, especially the need for unity. The people (povu) also understand that agricultural productivity - traditionally associated with ritual leaders - is the precondition of a vibrant nation. Where the agricultural rites staged by ritual leaders symbolically reunite the realm as a whole, the unified nation is constructed by the people in the liberation struggle. Above all, the people resemble ritual authorities through their productive suffering. Their agonistic 'purchase' of the national flag resonates with the Christian economy of salvation, but it also evokes the ideology of animist rituals, wherein those who suffer to bring something forth must be repaid for their 'fatigue' (kolen). Traditionally, the position of a suffering source belonged to status superiors - the cosmic beings themselves and the ritual leaders who were their human counterparts and guardians. 
Today, it also belongs to the mass of ordinary, rural folk, most of them poor and illiterate, who sacrificed themselves for the nation and now demand that the state repay them for their 'fatigue'.

A post-colonial state that ignores aspirations nurtured during an anti-colonial national liberation struggle puts its legitimacy at risk (Davidson 1992:214-15). In Timor-Leste, the post-independence years have seen a breakdown of trust in the national leadership, which the 2007 parliamentary elections failed to overcome (McWilliam and Bexley 2008: 79). When I visited Aileu briefly after the elections, Fretilin was the main target of popular grievances and faith in a new coalition government led by the CNRT (Conselho Nacional de Reconstrução do Timor, the National Congress for Timorese Reconstruction) was cautiously voiced. But I had the sense that people were already bracing themselves for further disappointment from the new national leadership. Indeed, East Timorese political leaders, whatever their party affiliations, face an ideological dilemma: whereas indigenous political culture once legitimised outsider rulers, legitimacy now depends on claims to insider status that very few individuals can authenticate.

Xavier do Amaral is a partial exception. In 2001, Xavier had founded a party he named ASDT (Associacao Social Democratica Timorense, the Timorese Social Democratic Association), which was the original name of Fretilin. In Aileu, ASDT was received as Fretilin's original 'trunk' or 'source', and it has won substantial majorities in every election. ${ }^{19}$ Xavier is a Mambai from the district of Ainaro, and his ethnicity as well as his matrimonial connections with important Aileu families have contributed to his popularity, but his greatest asset is the aura of interiority he projects. Xavier has consistently aligned himself with the 'inner' pole of the political plane, as the elder, peace-oriented chief who 'cools' the land after war. ${ }^{20}$ While his supporters do not seem to expect much from him in the way of policy, he is widely praised (even by members of other parties) as a unifying counterforce to the perceived egoism and divisiveness of most state elites, a wise 'grandfather' (tata) who puts the welfare of the people before all else. Such esteem for Xavier was itself symptomatic of frustration with politics as usual. A still more telling index of popular mistrust of the state was the

19 Much was also made of Xavier's role as fundador, ('founder') of Fretilin; although the term is derived from Portuguese, I have always suspected that for many Mambai it evokes their botanical origin category $f u$. 20 After the Indonesian invasion, Nikolau Lobato oversaw military operations for the resistance, while Xavier confined himself to political matters; Xavier's growing lack of confidence in a military solution and his pursuit of a negotiated settlement led to his being deposed and charged with treason by Fretilin. He was later captured by the Indonesians. During the UN-administered transition, many people anticipated the day when Xavier would preside over a ceremony to 'put away the sharp and pointed things'. 
considerable regard for another Mambai, the renegade Major Alfredo Reinado, whom many of my friends proudly described in July 2007 as a 'defender of the people' ${ }^{21}$

Such disillusionment with the national-state is indicative of the strength rather than the weakness of popular nationalism. The nation is the discursive site for a critique of the state that draws on pre-national traditions. From the vantage point of the imagined nation, the state is obligated to provide for the welfare of the people; its perceived failure to do so leaves the people in the position of the donor and defines their suffering as an unreciprocated gift. The situation is in some ways comparable with that of Hohul and Raimaus, where the selfdefined founders of the realm continued to claim respect from Aileun chiefs who neglected and allegedly abused them; when the chiefs (by some accounts) sent the militias to burn their 'old mother/old father' in 1999, their legitimacy came into question (Traube 2007). Today, the legitimacy of the national-state depends on its willingness and ability to recognise and repay its founders.

\section{Acknowledgments}

This chapter is based on research pursued between 1973 and 1974 (supported by grants from the National Science Foundation and the National Institute of Health) and since 2000. I first returned to Aileu in October 2000 for approximately nine months of fieldwork; this work was supported by grants from the Wenner Gren Foundation and Wesleyan University. I returned again for two months in 2002, with the help of a summer research grant from the National Endowment for the Humanities, and in July 2007, I visited several Mambai districts, including Aileu, as an election observer for the Carter Center. A short version of this paper was published as Traube, E., 2011, "Producing the People", in Kathleen M. Adams and Kathleen A. Gillogly (eds), Everyday Life in Southeast Asia, Indiana University Press, Bloomington, pp .247-57.

21 I suspect, although I cannot pursue the point here, that Alfredo might have evoked at some level the sentinels who traditionally surrounded and guarded sacral centres. 


\section{References}

Anderson, B. 1998, 'Gravel in Jakarta's shoes', in The Spectre of Comparisons: Nationalism, Southeast Asia and the world, Verso, London and New York, pp. $131-8$.

Bellwood, P. 1996, 'Hierachy, founder ideology and Austronesian expansion', in James, J. Fox and Clifford Sather (eds), Origins, Ancestry and Alliance: Explorations in Austronesian ethnography, Research School of Pacific and Asian Studies, The Australian National University, Canberra, pp. 18-40.

Cunningham, C. E. 1965, 'Order and change in an Atoni diarchy', Southwestern Journal of Anthropology, vol. 21, pp. 359-82.

Davidson, B. 1992, The Black Man's Burden: Africa and the curse of the nationstate, Times Books, New York.

Dunn, J. 2003, East Timor: A rough passage to independence, Longueville Books, Double Bay, NSW.

Durand, F. 2001, 'Timor Lorosa'e 1930-2001: Partis politiques et processus électoraux à hauts risques', Aséanie, vol. 8, pp. 103-26.

Fox, J. J. 1995a, 'Austronesian societies and their transformations', in Peter Bellwood, James J. Fox and Darrell Tryon (eds), The Austronesians: Historical and comparative perspectives, Department of Anthropology, Comparative Austronesian Project, Research School of Pacific Studies, The Australian National University, Canberra, pp. 229-43.

Fox, J. J. 1995b, Installing the outsider inside: the exploration of an epistemic Austronesian cultural theme and its social significance, [Revised draft], Paper presented at the first Conference of the European Association for Southeast Asian Studies: Local Transformations and Common Heritage in Southeast Asia, 29 June - 1 July, Leiden University, Netherlands.

Fox, J. J. 1996, 'Introduction', in James J. Fox and Clifford Sather (eds), Origins, Ancestry and Alliance: Explorations in Austronesian ethnography, Department of Anthropology, Comparative Austronesian Project, Research School of Pacific and Asian Studies, The Australian National University, Canberra, pp. $1-17$.

Guha, R. 1982, 'On some aspects of the historiography of colonial India', in Ranajit Guha Delhi (ed)., Subaltern Studies I: Writings on South Asian history and society, Oxford University Press, Oxford and New York, pp. 1-8. 
Guha, R. 1997, Dominance Without Hegemony: History and power in colonial India, Harvard University Press, Cambridge, Mass., and London.

Harvey, G. 2006, Animism: Respecting the living world, Columbia University Press, New York.

Henley, D. 2002, Jealousy and Justice: The indigenous roots of colonial rule in northern Sulawesi, VU University Press, Amsterdam.

Kelly, J. D. and Kaplan, M. 2001, Represented Communities: Fiji and world decolonization, University of Chicago Press, Chicago.

Lazarus, N. 1999, Nationalism and Cultural Practice in the Postcolonial World, Cambridge University Press, Cambridge and New York.

Li Puma, E. and Meltzoff, S. 1990, 'Ceremonies of independence and public culture in the Solomon Islands', Public Culture, vol. 3, no. 1, pp. 77-92.

McWilliam, A. 2002, Paths of Origin, Gates of Life: A study of place and precedence in southwest Timor, KITLV Press, Leiden, Netherlands.

McWilliam, A. and Bexley, A. 2008, 'Performing politics: the 2007 parliamentary elections in Timor Leste', Asia Pacific Journal of Anthropology, vol. 9, no. 1, pp. 66-82.

Pélissier, R. 1996, Timor en Guerre, Le Crocodile at les Portugais (1847-1913), Pélissier, Orgeval, France.

Sahlins, M. 1985, Islands of History, University of Chicago Press, Chicago.

Scott, J. C. 1990, Domination and the Arts of Resistance: Hidden transcripts, Yale University Press, New Haven, Conn.

Spivak, G. C. 1988, 'Can the subaltern speak?', in Cary Nelson and Lawrence Grossberg (eds), Marxism and the Interpretation of Culture, University of Illinois Press, Urbana, pp. 271-313.

Taylor, J. 1999, East Timor: The price of freedom, Zed Books, London and New York.

Therik, T. 2004, Wehali, The Female Land: Traditions of a Timorese ritual centre, Department of Anthropology, Research School of Pacific and Asian Studies, The Australian National University, in association with Pandanus Books, Canberra.

Traube, E. G. 1986, Cosmology and Social Life: Ritual exchange among the Mambai of East Timor, University of Chicago Press, Chicago. 
Traube, E. G. 1989, 'Obligations to the source', in David Maybury-Lewis and Uri Almagor (eds), The Attraction of Opposites: Thought and society in a dualistc mode, University of Michigan Press, Ann Arbor, pp. 321-44.

Traube, E. G. 1995, 'Mambai perspectives on colonialism and decolonization', in P. Carey and G. Carter Bentley (eds), East Timor at the Crossroads: The forging of a nation, Social Science Research Council, London, pp. 42-55.

Traube, E. G. 2007, 'Unpaid wages: local narratives and the imagination of the nation', Asia Pacific Journal of Anthropology, vol. 8, no. 1, pp. 9-25.

Valeri, V. 1989, 'Reciprocal centers: the Siwa-Lima system in the cCentral Moluccas', in David Maybury-Lewis and Uri Almagor (eds), The Attraction of Opposites: Thought and society in a dualistic mode, University of Michigan Press, Ann Arbor, pp. 117-41. 